\title{
Local GIS: development and assessment of the geoportal for local governments and local communities. Case study of a small town in Poland
}

\begin{abstract}
Of the numerous applications of GIS, administration and public services count among the main fields of application. They are both the users and the owners of the largest amount of spatial data. Portals for higher authorities have been the subject of extensive discussions, but the development and possible use of GIS systems in the form of geoportals at local levels still seems to have been insufficiently discussed.

This article presents the process of designing and developing a portal for the lowest authorities - local authorities and the local community. A small town in Poland, Sokółka, was assumed as the study area. The concept development was preceded by, among others: recognition of the needs of an administrative unit in conducting spatial policy; establishment of the objectives, functionalities and assumptions of the designed GIS; a SWOT analysis of the designed geoportal; and an analysis of data resources. Pilot implementation was completed with an evaluation of the geoportal encompassing various groups of potential users.
\end{abstract}

Keywords

Local GIS • geoportal • local governments • local level administration

(C) University of Warsaw - Faculty of Geography and Regional Studies

\author{
Katarzyna Medolińska, \\ Izabela Gołębiowska, \\ Izabela Karsznia \\ Department of Geoinformatics \\ Cartography and Remote Sensing, \\ Faculty of Geography and Regional Studies, \\ University of Warsaw, Poland \\ e-mail: medolinska.katarzyna@gmail.com \\ e-mail: i.golebiowska@uw.edu.pl \\ e-mail: i.karsznia@uw.edu.pl \\ Received: 4 July 2017 \\ Accepted: 23 October 2017
}

Introduction

Geographic information systems (GIS) are based on spatial information and include a large range of applications. Among the numerous applications of geoinformation systems, two of the main application fields are administration and public services (Gotlib et al. 2007, ed. Zwoliński 2009), which both use and possess the largest amount of spatial data (Tomlinson 2013). Officials are aware of the need to rationally use the existing resources and to improve the quality of the offered services, and GIS offers a wide range of tools for these purposes. It seems natural that local authorities are interested in improving decision-making processes - it is estimated that $70-80 \%$ of decisions made by local authorities are spatial in nature (Longley et al. 2005).

Portals for higher authorities (e.g., national, international) are frequently developed, discussed and widely known, both in general (Goodchild et al. 2007, Maguire \& Longley 2005, Tang \& Selwood 2005 ) and because of the Member States of the European Union implementing the INSPIRE Directive (INSPIRE GEOPORTAL n.d., Waters et al. 2011) or transposing the Directive into national law in the form of a National Spatial Data Infrastructure (Geoportal 2 n.d.). Moreover, on the regional level there also exist numerous successful geoportals such as Masovia Gate, Podlaskie Gate or Świętokrzyskie Gate based on the SDI Module by the Head Office of Geodesy and Cartography. Despite this fact, the development and possible use of GIS geoportals at the local administration level still appears to have been insufficiently discussed (Chojka 2009). The aim of this research was to develop a low cost solution tailored to the specific needs of local administration. Thus, we wanted to avoid the use of general purpose implementation solutions, such as SDI Module, or expensive products offered by large commercial vendors (e.g. ESRI, GEO-SYSTEM, GEOBID).

The process of developing the concept of a spatial information system for Sokółka, a small town in Poland, was described, focusing especially on ensuring high utility of the portal. Development of the concept was preceded by, among others, identification of the needs of administrative units in spatial policy, and establishment of the objectives, functionality and assumptions of the GIS to be designed. Having completed the pilot implementation a quantitative and qualitative evaluation of the proposed methodology was conducted. Qualitative evaluation included a SWOT analysis that exposed the benefits and constraints of the designed methodology. Meanwhile, quantitative evaluation was ensured by a survey conducted among various groups of potential users. We concluded with a list of benefits resulting from the implementation of the developed methodology.

GIS development issues at the local administration level

GISs designed nowadays are not as expensive as they used to be, and can therefore be commonly applied at all levels of government administration: starting from legislation at the central level, through regional policy, to local decisions and social participation (Fig. 1).

Numerous applications of GIS, including those at the local level, do not always go hand in hand with the standard needs of their future users in relation to spatial data resources owned and legal regulations (Harvey et al. 2012). Over the years, more and more GISs have been developed. They often are not compatible and data exchange between them is very difficult 


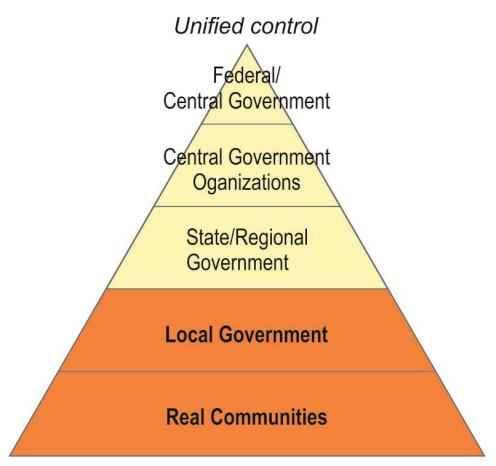

Acknowledges heterogeneity

Figure 1. Use of GIS in the decision-making activities at different levels of government structures (Source: based on Longley et al. 2005)

or even impossible. Frequently, different institutions create their own spatial resources and do not care about their own data being compliant with data belonging to other institutions. Thus, numerous databases are created which cannot be integrated or jointly used. At the same time, efforts in the process of obtaining often the same data are multiplied, resulting in additional costs (Wdowienko \& Protasiewicz 2009, Baranowski 2011).

Significance of local GIS development for communities and social participation

Social participation, which we take to mean activities aimed at sharing geographic information systems and other tools supporting decision-making processes for all groups of users concerned, is also an interesting issue related to geoinformation systems (Schroeder 1996, Sieber 2006). Appropriate use of GIS in public administration significantly contributes to increased transparency in municipal decision-making processes, which creates solid foundations for residents to get involved in decisionmaking processes regarding key matters within local areas. Legal regulations favour the greater interest of residents in the actions of municipal authorities. For example, adoption of the new Regulations for the work of the Council of Ministers dated 29 October 2013 indicates that conducting consultations is becoming more and more important for Polish authorities. This is a significant aspect, as up to $70 \%$ of Poles believe that they do not have any influence on national matters, and $47 \%$ of them - on local matters regarding their city or municipality (Makowski 2014).

A questionnaire survey regarding public consultations in Poland indicated that $60 \%$ of the respondents were not interested in the activities of municipal authorities. Twenty percent of the respondents knew the concept of public consultations. The need for consultations related to spatial management and within locations of large investments was indicated by $20 \%$ of the respondents. At the same time, within the last two years only $7 \%$ of the respondents participated in public consultations regarding policy conducted at the local level, but up to $57 \%$ of them indicated that they had to care for expressing their opinion on their own. Practically, this may indicate either local authorities' inactivity with regard to enabling citizens to participate in the consultation process or the ineffectiveness of their methods for informing residents about organised consultations (Popławska 2014).

Studies indicate that there is still a lot to do in the scope of social participation in Poland, despite the modern preference for the participation of citizens in the decision-making processes of the authorities. One important role of geographic information systems is frequently presented in the context of social participation, and is known as participatory GIS (e.g. Elwood 2006, Cinerby et al. 2008). For this reason public administration employees become aware that multifaceted computerisation which also involves offices and geoinformation technologies should be applied more broadly. The purpose of all this is to provide the local community with information within a given area. Additionally, the possibility for residents to participate in decision-making processes favours acceptance for administrative decisions and implementation of the planned investments (Jędrzejczak 2011).

One effect of the social participation is joint decision-making by the local community on key issues relating to the sustainable development of the municipality. This is not only a good practice, but also an obligation resulting from certain legal acts, e.g. the Act of law of April 24th 2003 on Public Benefit and Volunteer Work, which oblige public administration bodies to cooperate with non-governmental organisations on activities of benefit to the public.

Despite numerous examples showing that active social participation is generally at the beginner level in Polish municipalities, there are positive signals indicating that it is all going in the right direction. This is because civil and information society is gradually being built (Papińska-Kacperek 2008) and a lot of support is being offered by academic circles. These provide local communities access to spatial data and communication in numerous comfortable forms which help citizen involvement to grow: online discussions on various forums, e-surveys, workshops, consultations and public meetings, traditional surveys, polls, interviews, etc. Generally, notices and advertisements in the press and leaflets create fewer opportunities to involve citizens (Centrum UNEP/GRID-Warszawa 2011). It is worth working on this aspect, as people constitute a valuable component of GIS and the success or failure of implementing GIS depends on the human factor, and not on technology (Bielecka \& Maj 2009).

\section{Sokółka Geoportal: design and development}

Study area

The town of Sokókka was selected as the study area as it is currently undergoing changes in policy resulting from the shift from the agricultural to the services sector. The process requires effective management of space and all resources. Moreover, small towns with population lower than 50,000 seemed to be the most appropriate place to present the typical challenges of constructing a GIS for local authorities and communities.

The town of Sokółka is located in north-eastern Poland. It has approximately 20,000 inhabitants and it covers an area of approx. $18.5 \mathrm{~km}^{2}$. Sokółka is the seat of the authorities of Sokółka county and the Sokółka urban-rural municipality. It is $16 \mathrm{~km}$ from the border with Belarus (Fig. 2).

Currently the agricultural function of the municipality is decreasing in comparison to increasing significance of services and investments in the town. The appropriate decision of the authorities regarding the direction of the spatial policy being conducted is therefore very important. Certainly the municipality will not give up attracting investors, as real estate tax constitutes the largest source of income of the municipality regarding public levies.

Due to landscapes and historical value, ecotourism in the municipality is developing intensely. It brings less income to the municipality, however attracting tourists can cause significant economic revival of the municipality. The above analysis shows the significance of the potential of a geoinformation system for the entire municipality.

Regardless of the decision of the authorities concerning the direction of the spatial policy being conducted, the analysis of the study area indicates that a significant advantage is the versatility 


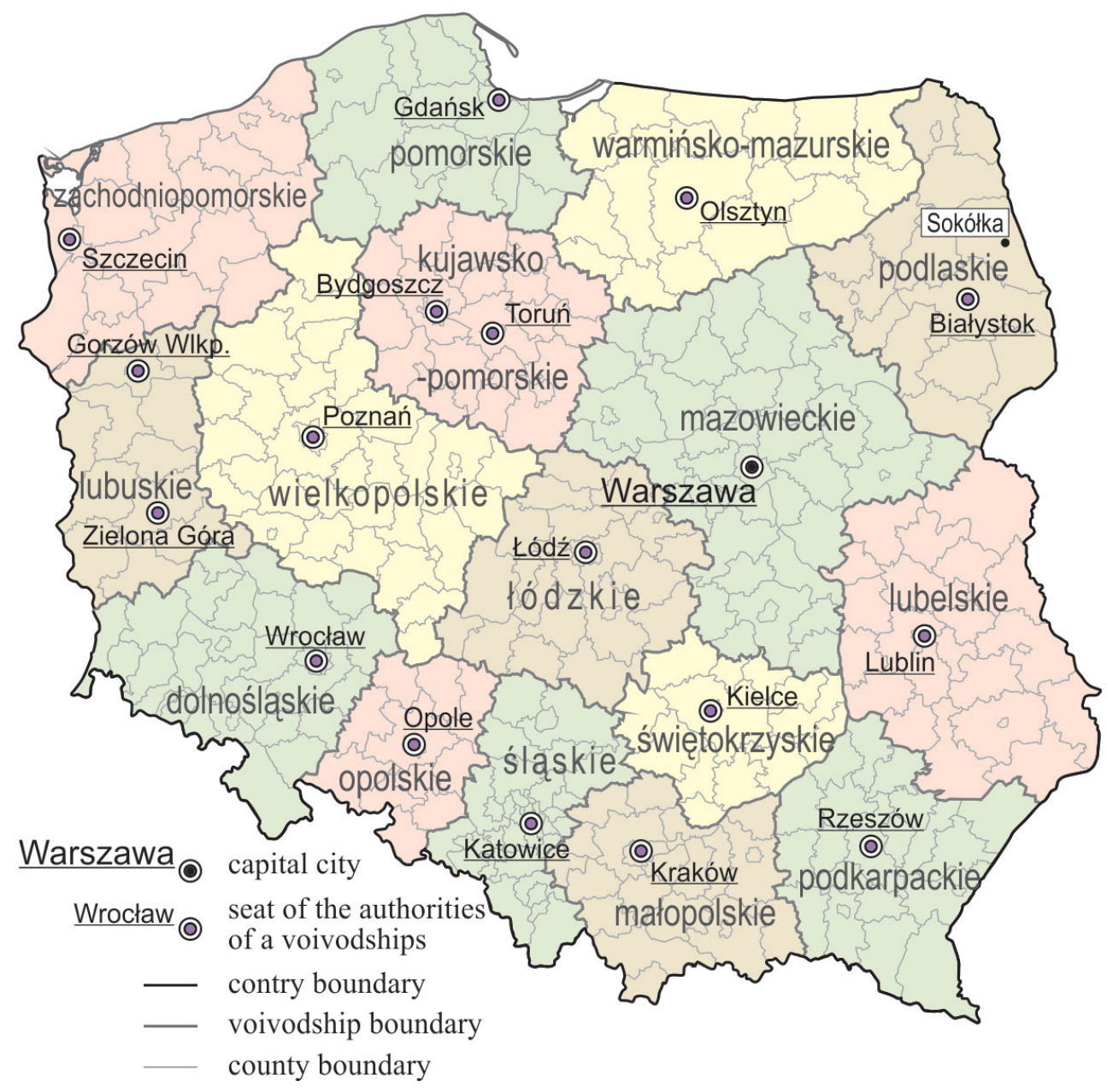

Figure 2. Location of Sokółka in the administrative division of Poland (Source: own elaboration)

of the designed GIS for Sokółka and access to integrated spatial information can bring numerous benefits. Investors and tourists can benefit from that. Development of the geographic information system would also be beneficial for the authorities of the municipality. It would provide them with organised spatial information in a legible form. It would also allow the local community to access the gathered and harmonised information.

\section{Objectives of the planned GIS}

The decision to create a GIS portal brings changes in policies relating to how a given organisation functions - in this case an administrative unit of local government. Based on conversations conducted with governmental employees from Sokółka and the analysis of strategies, plans and resolutions, the objectives of the geoinformation system were determined in accordance with the objectives of the administrative unit. From the perspective of the spatial policy - which is related mainly to ecotourism and mining within the municipality on the one hand, and services, industry and pilgrim tourism within the town on the other - the general objective of the governmental unit appears to be simpler and more effective attraction of investors. Other important objectives of introducing GIS in Sokółka include improvement of spatial management and popularisation of the use of geoinformation technologies. There are also specific project objectives related to promoting the town and increasing the quality of services provided by the office, as follows:
- improving the functioning of administrative structures by shortening the decision time in spatial planning, investment processes and the rational management of municipal property,

- $\quad$ supporting customer service and implementation of internal procedures of the office and other tasks related to spatial policy with regard to administrative activities,

- ordering and integration of spatial data owned by the Sokółka Town and Municipality Office and the District Office in Sokółka, which constitutes basis to build Local Spatial Data Infrastructure,

- obtaining information about potential spatial conflicts within the town,

- $\quad$ ensuring that residents of the town have common access to spatial data presented in a reasonable graphic form,

- stimulating tourism infrastructure development and promoting the natural and cultural value of Sokółka.

The determined assumptions have a direct impact on the functionality of the designed GIS, which means ensuring that the range of functions is compliant with users' needs (Sikorski 2004).

\section{Methodology}

The proposed methodology aimed to develop a geoportal which fulfilled certain conditions. Firstly, it should be tailored to the needs of the local community that wants to efficiently manage the gathered spatial data. Secondly, it should minimise all the 

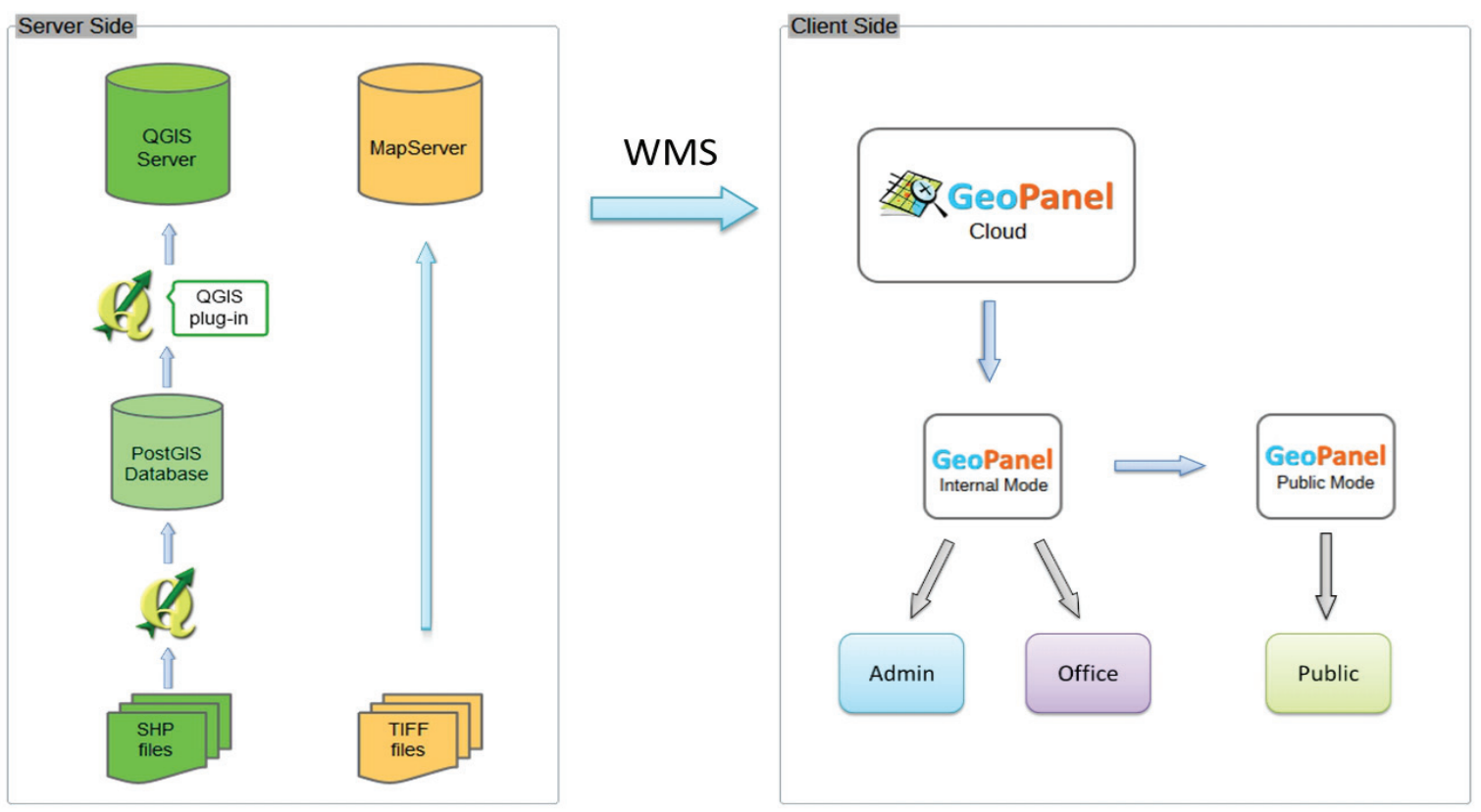

Figure 3. Functional diagram of the GEOPANEL application on the server and client side (Source: own elaboration)

costs associated with design and implementation of a geoportal. Finally, it should result in a tool that would be helpful for a varied and diverse groups of users.

\section{Software}

The basis of this GIS project is a GEOPANEL application, developed by a technological partner of the project - the UNEP/GRID-Warsaw Centre, a department of the National Foundation for Environmental Protection. The application offers the management of own spatial data and the ability to share it in the form of services. It also integrates the resources of the national spatial information infrastructure available via spatial data services. GEOPANEL also has a module to conduct public consultations and other arrangements between institutions based on designs created in the application and the content presented in them (Centrum UNEP/GRID-Warsaw 2012).

Full use of the GEOPANEL application, by adding one's own files, is possible through the use of the installed open source software QGIS (previously called Quantum GIS). The program allows one's own spatial resources to be processed, data to be created, spatial analysis to be conducted and map presentations to be created from spatial resources and shared. The functionality of the program is significantly expanded by plug-ins, i.e. additional extensions of the application. A plug-in has been developed for the needs of the GEOPANEL application which allows one's own spatial data to be shared in the form of a WMS service.

Spatial data from the GEOPANEL application is stored in an open source database - PostgreSQL. The database contains the PostGIS extension which allows spatial data to be saved directly in the database. The pgAdmin platform, written in the $\mathrm{C}++$ programming language, is used to administer and develop the base.

In this project the ArcGIS 10.0 package was also used. The ArcGIS software was treated as complementary software for QGIS and some data operations were conducted in it. Additionally, Adobe Photoshop, Inkscape and PhotoFiltre were used to correct images. The technical functional diagram of the geoportal for Sokółka is presented in Fig. 3.
The GEOPANEL application functions are based on a clientserver architecture. Each user of the application (client) who sends a query to the server, communicates with it using the WMS service. In response, the server with the GIS application, cooperating with the database, sends a response upon request of the userclient. On the server side there are two methods of working with files, depending on their format. TIF files are directly placed on the MapServer, which is a free tool for sharing spatial data online. SHP files, before they are placed on the server, and after appropriate software configuration, are imported to the database of the GEOPANEL - the PostgreSQL application. There the data is processed and, as a PostGIS layer, can be saved in the QGIS Server database, which is fully integrated with the QGIS program.

\section{Spatial data}

Data is a pillar of geoinformation systems. In the project, five different thematic layers were distinguished. By order of display they are:

- Registry of lands and buildings,

- Local spatial management plans (seven plans including 12 graphic attachments),

- Study of conditions and directions of spatial management,

- Eco-physiographic elaborations (eco-physiography),

- Town plan.

Local plans, the study of conditions and the eco-physiographic elaboration are raster files which belong to the Sokółka Town and Municipality Office. The registry of lands and buildings is vector data and belongs to the District Office in Sokókka, while the town plan is the elaboration of the project's author. Apart from the above mentioned thematic layers, the users can - for their own needs - add view services with raster data from the following industry portals:

- Geoportal 2: cadastral data, an orthophotomap, the National Register of Boundaries, the National Register of Geographical Names and a topographic map (VMap Level 2),

- The General Directorate for Environmental Protection protected areas. 


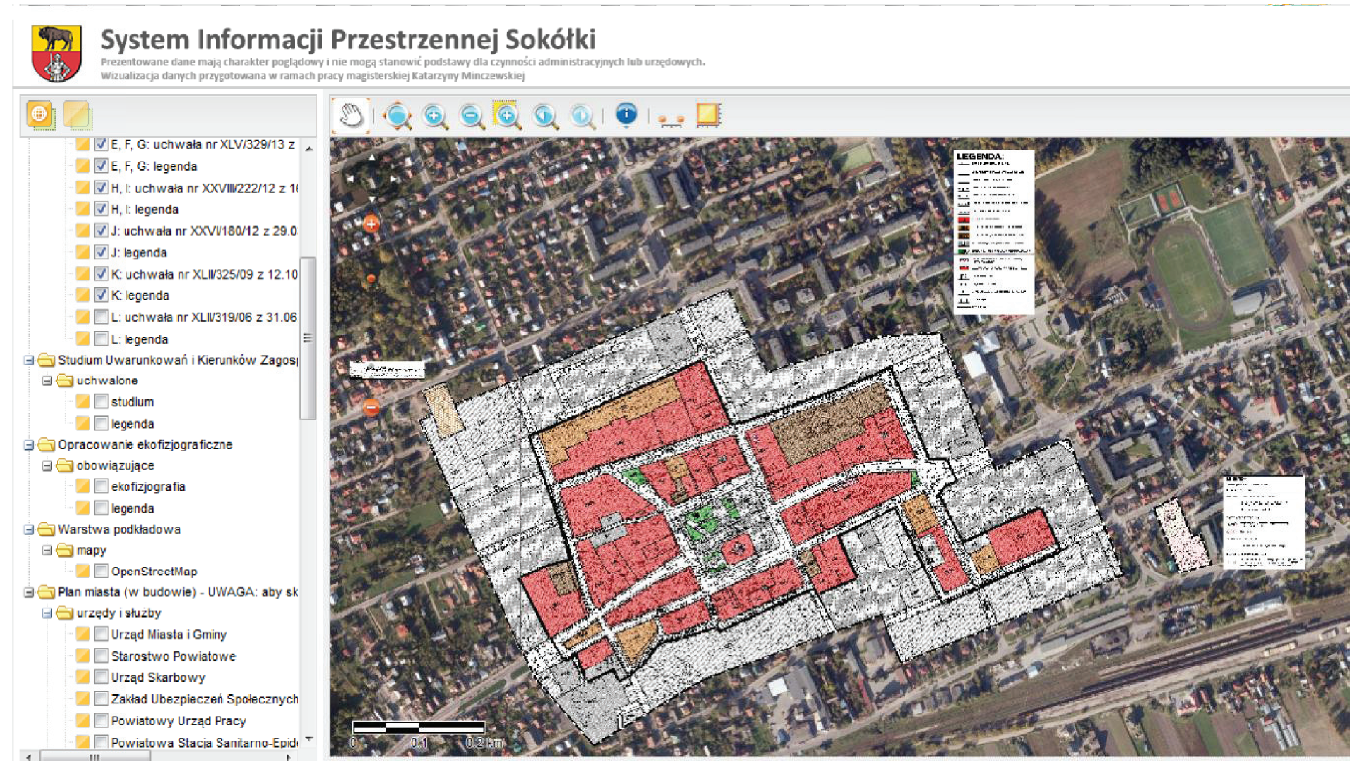

Figure 4. The geoportal interface available to residents and tourists as an interactive map (Source: own elaboration)

\section{Geoportal functionality}

The developed GIS is characterised by different functionality for various users. The public module belongs to the sphere of interaction between government employees and residents of the municipality. The final effect is an interactive map presenting data visualisation which was made available online - Geoportal of Sokółka (Fig. 4). From this level the user can:

- review data from the registry of lands and buildings, local spatial management plans, eco-physiographic elaborations and the town plan,

- display information related to objects placed in the town plan and data from other sources, including the national geoportal and industry portals.

Besides the functionality of the public module, the module for officials also allows users to:

- search and print an area at a desired scale,

- conduct online consultations related to spatial policy,

- create new designs and complete modifications of existing ones with the option to add more maps to the designed GIS.

The administrator module is used to manage resources available on the geoportal and their configurations.

\section{Assessment}

After conducting the pilot implementation and publishing the Geoportal of Sokółka on the website of the Town Office in Sokółka, of the proposed methodology was evaluated among its potential recipients in the form of a survey. Additionally, on the basis of the author's own observations and conversations with government employees, an economic cost-benefit analysis of the implementation of GIS in Sokółka was performed.

\section{SWOT analysis}

Within the proposed methodology of the pilot implementation, a SWOT analysis was prepared, which is an analysis of strengths, weaknesses, opportunities and threats related to the implementation of the project (Tab. 1). This analysis was used to organise information on various types of elements, e.g. the external and internal environment of various types of objects (e.g., Jędrusik et al. 2015) and projects. It was assumed that strengths and weaknesses of the project concern the current conditions, and that they directly result from the organisation and they can be affected by decisions related to the design of the GIS solution, while opportunities and threats are phenomena which may occur in the future and are external factors independent of the project. The analysis allowed the most important factors positively and negatively influencing the implementation of the project to be identified, suggesting selection of an appropriate action plan when creating a GIS.

The SWOT analysis allows it to be stated that the GIS project for Sokółka has a lot of weaknesses and requires various actions in numerous fields. Most of all, it is important to focus on working with human capital and to consider the matter of enabling interoperability between data resources. A good project environment is very helpful here, mainly in the form of legal regulations (INSPIRE Directive and the Act on Spatial Information Infrastructure).

\section{Survey among various groups of potential users}

Sixty respondents participated in the online survey: 24 residents of Sokółka, 13 tourists, 9 investors, 8 people related to the GIS industry and 6 government employees. The results of the survey indicate the positive attitude of respondents to the town geoportal. As many as $93.3 \%$ of the respondents believe that residents should have access to spatial data in the form of a geoportal and they like the initiative. At the same time, $88.3 \%$ of respondents think that the application facilitates access to information about the town space. Ninety percent of the respondents declare their willingness to use the geoportal before they go to the Office regarding spatial planning and investment processes - importantly, $100 \%$ of the investors gave a positive answer in this matter. The users' responses to questions about the functionality of the portal were also predominantly positive (Fig. 5).

People related to the GIS industry stated their opinion more than just in the survey. Information about launching of the Geoportal of Sokółka was published on geoforum.pl. There, four 
Table 1. SWOT analysis for the GIS portal implementation

\begin{tabular}{|c|c|}
\hline Strengths & Weaknesses \\
\hline $\begin{array}{l}\text { - } \quad \text { gathering data resources in one place } \\
\text { participation of an employee of the Office in the INSPIRE } \\
\text { Directive implementation } \\
\text { - } \quad \text { presence of an employee dedicated to IT within the Office } \\
\text { interest of residents in having access to information } \\
\text { significant cost reduction through implementation in } \\
\text { an open source software and use of data obtained } \\
\text { free of charge from the County Centre of Geodetic } \\
\text { and Cartographic Documentation and the Town and } \\
\text { Municipality Office. }\end{array}$ & $\begin{array}{l}\text { - lack of preparation of employees of the IT Department to } \\
\text { handle GIS software } \\
\text { moderate involvement of town authorities and government } \\
\text { employees in the implementation of the GIS project } \\
\text { resistance of employees of the Office to the continuous } \\
\text { introduction of changes } \\
\text { lack of vector data from the Town and Municipality Office, } \\
\text { preventing use of the full potential of GIS } \\
\text { lack of interoperability between data from the County } \\
\text { Centre of Geodetic and Cartographic Documentation, and } \\
\text { the Town and Municipality Office } \\
\text { lack of access to information } \\
\text { time-consuming planning and decision-making process in } \\
\text { the town }\end{array}$ \\
\hline Opportunities & Threats \\
\hline $\begin{array}{l}\text { strong legal framework supported by the Head Office } \\
\text { of Geodesy and Cartography (implementation of the } \\
\text { INSPIRE Directive in the country will be completed by } \\
2019^{1} \text { ) } \\
\text { numerous good practices related to the implementation of } \\
\text { GIS in local governments } \\
\text { data integration as a basis for the construction of Local } \\
\text { Spatial Data Infrastructure }\end{array}$ & $\begin{array}{l}\text { - } \quad \text { termination of the agreement regarding use of the } \\
\text { application free of charge } \\
\text { - } \quad \text { quick technological development } \\
\text { - } \quad \text { terms of office of the authorities }\end{array}$ \\
\hline
\end{tabular}

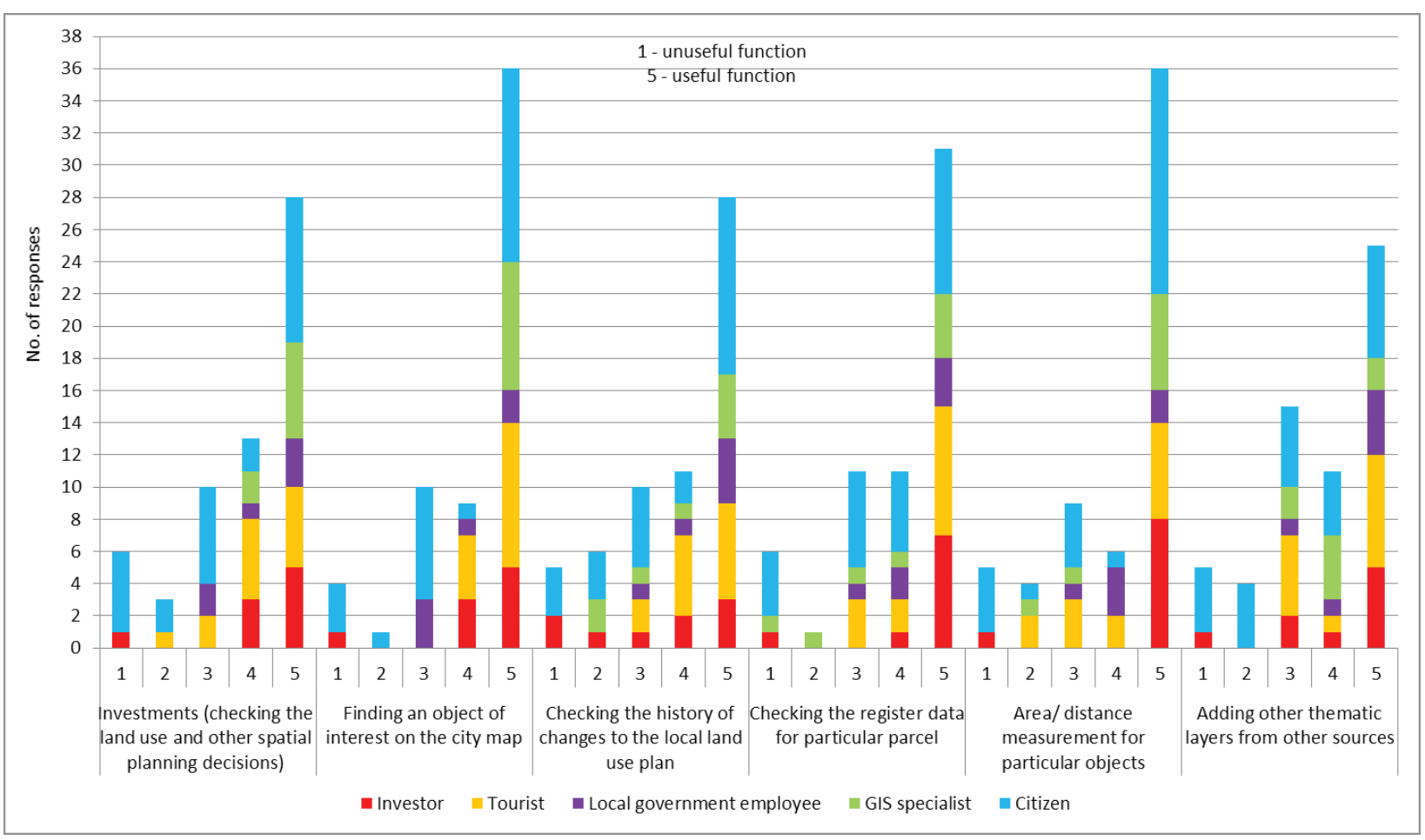

Figure 5. Respondent answers regarding geoportal functionality (Source: own elaboration)

readers also expressed their opinions and shared their comments regarding the project. Among the negative aspects of the project the following were mentioned: the lack of an instruction manual for each user, lack of contact with the developer, and the inability to create spatial queries. There were also two comments regarding the inability to display building functions.
Summary

Numerous benefits of the geoportal implementation can be pointed out, and include:

- ordering spatial information and easier access to data,

- obtaining information about spatial conflicts at the southwest town border, 
- increasing resident interest in the activities of municipal authorities thanks to the geoportal's public availability,

- $\quad$ substituting estimated statistical data with actual, measured data,

- versatility: the designed geoportal meets the needs of various user groups: government employees, investors, town residents and tourists,

- $\quad$ familiarising government employees with GIS technology.

Implementation of the proposed methodology increases access to spatial information, orders spatial data and indicates the existence of spatial conflicts which result from data resources not being interoperable. One of the fundamental objectives of the project implementation - harmonisation and coherence of spatial data - can be considered achieved.

The developed geoportal shows beneficial results of implementing GIS tools into the work of local administration and government. It can improve the functioning of numerous departments, increases local residents' interest in the spatial policy activities of the authorities, and is helpful to tourists and pilgrims. Moreover, the local geoportal can constitute a significant tool in supporting and stimulating social participation.

We believe that the developed geoportal will establish good practices in the development of local GIS, as there is an increasing number of cities and municipalities that use geoinformation systems (Chojka 2009).

\section{Acknowledgments}

The discussed geoportal was created in cooperation with the National Foundation for Environmental Protection, the Environmental Information Centre UNEP/GRID-Warsaw, the Mayor of the Sokółka Town and Municipality and the District Office in Sokółka. This research was supported by the Ministry of Science and Higher Education, Republic of Poland [project number DSM-110600].

\section{References}

Baranowski, M 2011, 'Infrastruktury geoinformacyjne oraz infrastruktura informacji przestrzennej w Europie' ['Geoinformation infrastructures and spatial information infrastructure in Europe'] in INSPIRE i Krajowa Infrastruktura Informacji Przestrzennej: podstawy teoretyczne $i$ aspekty praktyczne [INSPIRE and National Spatial Information Infrastructure: theoretical basis and practical aspects], eds S Białousz \& E Bielecka, Warsaw, pp. 67-85.

Bielecka, E \& Maj, K 2009, Systemy informacji przestrzennej: Podstawy teoretyczne [Spatial information systems: Theoretical basis], Wojskowa Akademia Techniczna, Warsaw.

Centrum UNEP/GRID-Warszawa 2011, 'Zrównoważony rozwój „małej ojczyzny”: współpraca gminy ze społecznością lokalną - partycypacja społeczna' ['Sustainable development of "the little homeland": cooperation of the municipality with local community - social participation'] in Zainspiruj się! Geoinformacja w samorządach gminnych [INSPIRE! Geoinformation in local governments], eds M Andrzejewska, P Mikołajczyk \& E Wołoszyńska, Centrum UNEP/GRIDWarszawa, Warsaw, pp. 138-142.

Centrum UNEP/GRID-Warszawa 2012, Instrukcja obsługiaplikacji GeoPanel [GeoPanel application instruction manual].

Cinderby, S, Snell, C \& Forrester, J 2008, 'Participatory GIS and its application in governance: the example of air quality and the implications for noise pollution', Local Environment: The International Journal of Justice and Sustainability, vol. 13, no. 4, pp. 309-320.

Chojka, A 2009, Adaptacja technologii MDA do budowy systemu geoinformacyjnego na poziomie gminy [MDA technology adaptation for the construction of a geoinformation system at the municipal level], Roczniki Geomatyki, vol. VII, issue 5(35), pp. 25-39.

Elwood, S 2006, 'Critical Issues in Participatory GIS: Deconstructions, Reconstructions, and New Research Directions', Transactions in GIS, vol. 10, no. 5, pp. 693-708.

Geoportal 2, n.d. Available from: <http://geoportal.gov.pl>. [30 October 2015]

Goodchild, MF, Fu, P \& Rich, PM 2007, 'Geographic information sharing: the case of the Geospatial One-Stop portal', Annals of the Association of American Geographers, vol. 97, no. 2, pp. 250-266.

Gotlib, D, Iwaniak, A \& Olszewski, R 2007, GIS. Obszary zastosowań [GIS. Application areas], Wydawnictwo Naukowe PWN SA, Warsaw.
Harvey, F, Iwaniak, A, Coetzee, S \& Cooper, A 2012, 'SDI Past, Present and Future: A Review and Status Assessment', in Spatially Enabling Government, Industry and Citizens, Research and Development Perspectives, eds A Rajabifard \& D Coleman, GDSI Association Press, Needham, USA, pp. 23-39.

INSPIRE GEOPORTAL, n.d. Available from: <http://inspiregeoportal.ec.europa.eu/>. [30 October 2015]

Jędrusik, M, Lisowski, A, Mouketou-Tarazewicz, D, Ropivia, ML \& Zagajewski, B 2015, 'Touristic development of the La Lopé National Park (Gabon) in light of the SWOT analysis', Miscellanea Geographica - Regional Studies on Development, vol. 19, no. 3, pp. 5-13.

Jędrzejczak, M 2011, 'Rozwój i innowacje w gminie - wspieranie działań w obszarze geoinformacji' ['Development and innovations in a municipality - supporting activities in the field of geoinformation'], in Zainspiruj się! Geoinformacja w samorządach gminnych [INSPIRE! Geoinformation in local governments], eds A Andrzejewska, P Mikołajczyk, \& E Wołoszyńska, Centrum UNEP/GRID-Warszawa, Warsaw, pp. 143-145.

Longley, PA, Goodchild, MF, Maguire, DJ \& Rhind, DW 2005, Geographic Information Systems and Science, John Wiley \& Sons.

Maguire, DJ \& Longley, PA 2005, 'The emergence of geoportals and their role in spatial data infrastructures', Computers, Environment and Urban Systems, vol. 29, pp. 3-14.

Makowski, G 2014, 'Public consultation in Poland: its legal basis and practice' INFOS zagadnienia społeczno-gospodarcze. Biuletyn Biura Analiz Sejmowych ['Public consultation in Poland: its legal basis and practice' INFOS social and economic issues. Bulletin of the Sejm Research Bureau], no. 20(180). Available from: <http://www.bas.sejm.gov.pl/ infos.php>. [5 January 2015].

Papińska-Kacperek, J 2008, Społeczeństwo informacyjne [Information society], Wydawnictwo Naukowe PWN SA, Warsaw.

Popławska, JZ 2014, 'Prawo do miasta - partycypacja społeczna w kształtowaniu miejskiej przestrzeni publicznej' ['Rights to the City - social participation in shaping urban public space'] in Oblicza społeczeństwa obywatelskiego. Państwo. Gospodarka. Świat. [Faces of civil society. State. Economy. World.], eds J Osiński \& JZ Popławska, Oficyna Wydawnicza Szkoła Główna Handlowa w Warszawie, Warsaw, pp. 123125 
Schroeder, P 1996, 'Criteria for the design of a GIS/2', NCGIA Initiative 19: GIS and society, Summer 1996.

Sikorski, M 2004, Funkcjonalność a użyteczność [Functionality vs. usability]. Available from: <http://hci.pjwstk.edu.pl/index. php?page=fun>. [03 December 2014)].

Sieber, R 2006, 'Public Participation Geographic Information Systems: A Literature Review and Framework', Annals of the Association of American Geographers, vol. 96, no. 3, pp. 491-507.

Tang, W \& Selwood, J 2005, Spatial Portals: Gateways to Spatial Information, ESRI Press, Redlands, CA.

Tomlinson, R 2013, Thinking about GIS: Geographic Information System Planning for Managers, ESRI Press, Redlands.
Waters, R, Beare, M, Walker, R \& Millot, M 2011, 'Schema Transformation for INSPIRE', International Journal of Spatial Data Infrastructures Research, vol. 16, pp. 1-22.

Wdowienko, AW \& Protasiewicz, EW 2009, 'Informatsionnyye tekhnologiiv sistemeupravleniyagradostroitielnym razvitiyem territorii munitsipalnogo obrazovaniya', Czasopismo Vestnik TOGU, no 4(15), pp. 8-14.

Zwoliński, Z (ed.) 2009, GIS platforma integracyjna geografii [GIS Integration Platform of Geography], Bogucki Wydawnictwo Naukowe, Poznań.

Legal acts

Directive 2007/2/EC of the European Parliament and the Council dated 14 March 2007 establishing spatial information infrastructure within the European Community (INSPIRE).

Regulations for the work of the Council of Ministers in Poland dated 29 October 2013

Act of law of April 24th 2003 on Public Benefit and Volunteer Work in Poland. 